\title{
Penerapan Sistem Pembelajaran Daring untuk Pembelajaran Bahasa Inggris di Teknik Mesin S1 ITN Malang
}

\author{
Tutut Nani Prihatmi ${ }^{1}$, Maria Istiqoma ${ }^{2}$ \\ ${ }^{I}$ Department of Mechanical Engineering, National Institute of Technology, Malang, Indonesia \\ ${ }^{2}$ Department of Architecture, National Institute of Technology, Malang, Indonesia \\ Email:tutut.nani@lecturer.itn.ac.id
}

\begin{abstract}
AbTRAKSI
E-learning merupakan pembelajaran yang dapat dilakukan dimana saja dan kapan saja, tergantung pada kebutuhan sumber daya manusia (pengajar, dosen, instruktur, dan peserta didik), sehingga memiliki potensi yang sangat besar untuk menghadapi tantangan dunia pendidikan khususnya Bahasa Inggris pada saat pandemic Covid19 ini. penelitian ini bertujuan untuk menganalisa pelaksanaan pembelajaran daring dalam Pembelajaran Bahasa Inggris di ITN Malang dalam masa pandemi sekaligus dalam rangka memasuki era revolusi industri 4.0, dan evaluasi terhadap implementasinya. Penelitian ini merupakan penelitian deskriptif studi kasus. Teknik pengumpulan data dilakukan dengan wawancara dan kuesioner. Penelitian ini dilakukan di ITN Malang pada semester genap 2019/2020. Populasi dalam penelitian ini adalah mahasiswa Teknik Mesin S1 ITN Malang angkatan 2019 yang mengambil Mata Kuliah Bahasa Inggris. TKT pada penelitian ini adalah TKT 3, karena merupakan pembuktian konsep (proof-of-concept) dari e-learning tersebut dan menggunakan rancangan metodologi yang tersusun. Tiga platform yang dipakai selama pembelajaran daring Bahasa Inggris yaitu Whatsapp, LMS SPADA ITN Malang, dan Zoom telah cukup memadai, membantu sharing atau penyampaian materi dalam pembelajaran, dan memudahkan dalam pengumpulan penugasan yang lebih terstruktur, meskipun ditemukan adanya beberapa kendala.
\end{abstract}

Kata Kunci Pembelajaran Bahasa Inggris, e-learning

\section{PENDAHULUAN}

\section{Konsep e-learning}

Dengan perkembangan teknologi internet yang pesat, pendekatan pembelajaran telah berubah menjadi berbasis digital. Saat ini peserta didik dapat belajar tidak hanya dimana saja tetapi sekaligus kapan saja dengan fasilitas sistem electronic learning yang ada. Wahono (2008) menyatakan bahwa e-learning merupakan suatu jenis belajar mengajar yang memungkinkan tersampaikannya bahan ajar ke siswa dengan menggunakan media internet, intranet atau media jaringan komputer lain. Secara sederhana dapat disimpulkan bahwa E-learning adalah istilah fleksibel yang digunakan untuk menggambarkan sarana pengajaran melalui teknologi.

Maudiarti (2018:54) menyebutkan bahwa dalam penerapan e-learning, ada beberapa proses komponen yang harus dilakukan, yaitu (1) konten yang relevan dengan tujuan belajar; (2) menggunakan metode pembelajaran (contoh dan praktik); (3) menggunakan elemen media seperti kalimat dan gambar; (4) pembelajaran dapat dilakukan secara langsung dengan instruktur (synchronous) ataupun belajar secara individu (asynchronous); serta (5) membangun wawasan dan teknik baru yang dihubungkan dengan tujuan belajar.

Dabbagh dan Ritland (2005:16) menyebutkan ada tiga kunci komponen dari pembelajaran daring bekerjasama untuk mengangkat arti pembelajaran dan saling timbal balik, yaitu (a) model pedagogi atau gagasan-gagasan; (b) strategi pendidikan dan pembelajaran; dan (c) alat-alat pedagogi, atau teknologi pembelajaran daring seperti internet dan teknologi berbasis jaringan.

\section{E-learning dalam Pembelajaran Bahasa Inggris}

E-learning dalam pembelajaran Bahasa Inggris perlu diciptakan seolah-olah peserta didik belajar secara konvensional, hanya saja dipindahkan ke dalam sistem digital melalui internet. E-learning perlu mengadaptasi unsurunsur yang biasa dilakukan dalam sistem pembelajaran konvensional.

Menurut Anderson dan Elloumi (2004), terdapat empat hal yang menjadi implikasi penggunan e-learning yang dapat diadaptasikan ke dalam kelas pembelajaran Bahasa Inggris dengan kondisi perkuliahan yang dilakukan secara daring dalam kondisi pandemi Covid 19 ini, yaitu: 
1. Mahasiswa harus menentukan secara eksplisit apa yang harus dihasilkan, sehingga dia dapat menentukan pilihan apa yang akan dipelajari.

2. Siswa harus dapat megevaluasi dirinya sendiri apakah berhasil atau tidak dalam pembelajaran e-learning secara daring. Ujian secara daring atau bentuk lain harus terintegrasi dalam tahapan pembelajaran untuk mengetahui perkembangan dan tingkat kemajuan Mahasiswa.

3. Bahan ajar harus memiliki tahapan yang memadai untuk menunjang pembelajaran. Tahapan dapat dalam bentuk sederhana maupun kompleks, mudah dan sulit, dan pengetahuan sampai aplikasi.

4. Mahasiswa harus dilengkapi dengan umpan balik sehingga dia dapat memantau apa yang telah dikerjakan dan memperbaiki kesalahannya.

Pada prakteknya, Pembelajaran Daring Bahasa Inggris di Teknik Mesin S1 ITN Malang memiliki 14 kali pertemuan yang 11 pertemuannya sudah dilakukan secara daring. Selama pembelajaran, digunakan 3 platform, yaitu melalui laman spada.itn.ac.id yang digunakan untuk membagi materi termasuk link untuk sumber belajar mandiri, melakukan absensi, dan pengumpulan tugas mandiri maupun kelompok; melalui grup Whatsapp sebagai sarana berkomunikasi dengan setiap kelas, dan Google Meet untuk melakukan presentasi maupun penjelasan materi dua arah.

\section{METODE}

Penelitian ini bertujuan untuk melihat dan mendeskripsikan bagaimana penerapan e-learning dalam pembelajaran Bahasa Inggris di Program Studi Teknik Mesin S1 Fakultas Teknologi Industri Institut Teknologi Nasional Malang pada semester Genap 2019/2020. Metode yang tepat untuk penelitian ini adalah studi kasus. Studi Kasus merupakan rangkaian kegiatan ilmiah yang dilakukan secara intensif, terinci dan mendalam tentang suatu program, peristiwa, dan aktivitas, baik pada tingkat perorangan, sekelompok orang, lembaga, atau organisasi untuk memperoleh pengetahuan mendalam tentang peristiwa tersebut (Rahardjo, 2013:3). Dalam Studi Kasus Prospektif (Prospective Case Study) ini perlu untuk menemukan kecenderungan dan arah perkembangan suatu kasus. Tindak lanjut yang dapat dilakukan dapat berupa Penelitian Tindakan yang dilakukan juga oleh pihak yang berkompeten. Dalam pelaksanaan penelitian ini, data yang dikumpulkan dan dikaji sebagian besar berupa data-data kualitatif. Instrumen yang dimanfaatkan dalam penelitian ini dapat dikelompokkan ke dalam dua kelompok sumber data, yaitu (1) informan/narasumber, dan (2) arsip/dokumen. Teknik pengumpulan data dilakukan dengan wawancara dan kuesioner. Penelitian ini dilaksanakan pada Maret 2020 sampai dengan Juli 2020. Dalam penelitian ini, komponen dalam analisis data meliputi Pengumpulan Data, Data Display, Data Reduction, dan Verifying (Gunawan).

\section{HASIL DAN PEMBAHASAN}

\section{Gender responden}

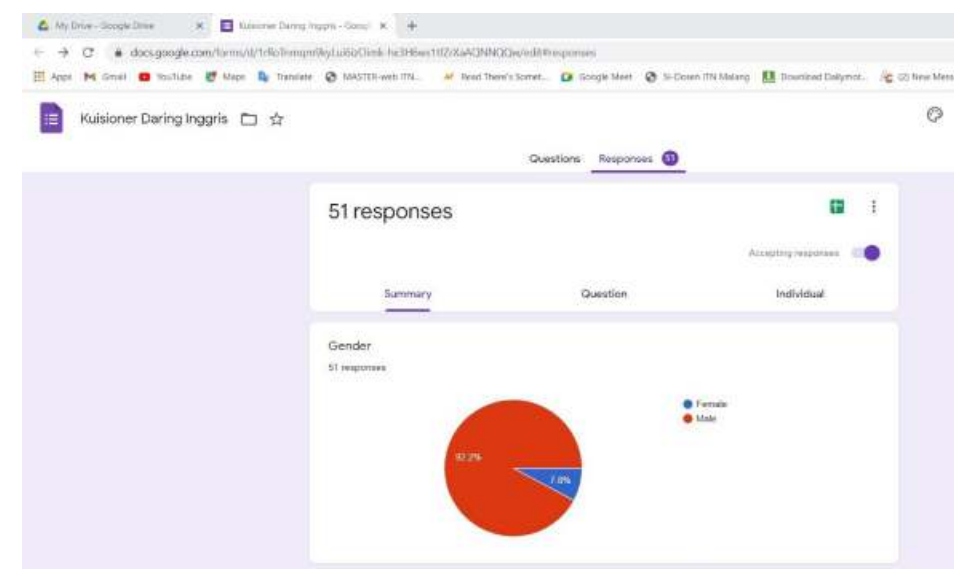

Fig. 1. Grafik Gender Responden

Dari 120 kuisoner yang disebarkan, respon yang didapat sejumlah 51 responden. Mahasiswa Teknik Mesin S1 adalah mayoritas laki-laki, jadi sesuai grafik pada Gambar 4, sejumlah 7,8\% yaitu 3 orang, adalah mahasiswa perempuan, selebihnya, 92,2\% yaitu 48 adalah laki-laki.

\section{Tipe aplikasi/platform yang digunakan}

Dalam pembelajaran daring, terdapat beberapa platform berbasis teknologi informasi yang seringkali dipergunakan sesuai kesepakatan kelas maupun kebijakan dosen. Dalam pembelajaran Bahasa Inggris, dosen memakai kombinasi dari beberapa platform. Secara rinci, Fig. 2. menunjukkan platform yang paling sering dipakai. 


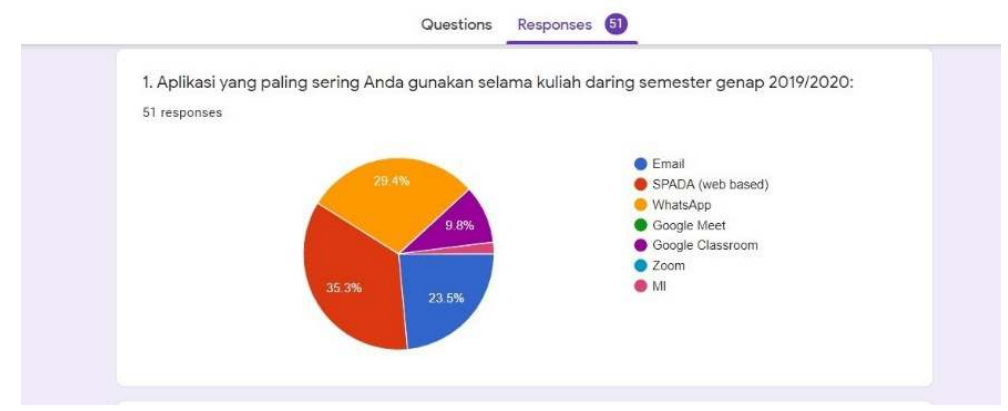

Fig. 2. Grafik tipe aplikasi yang digunakan

\section{Jenis perangkat yang digunakan}

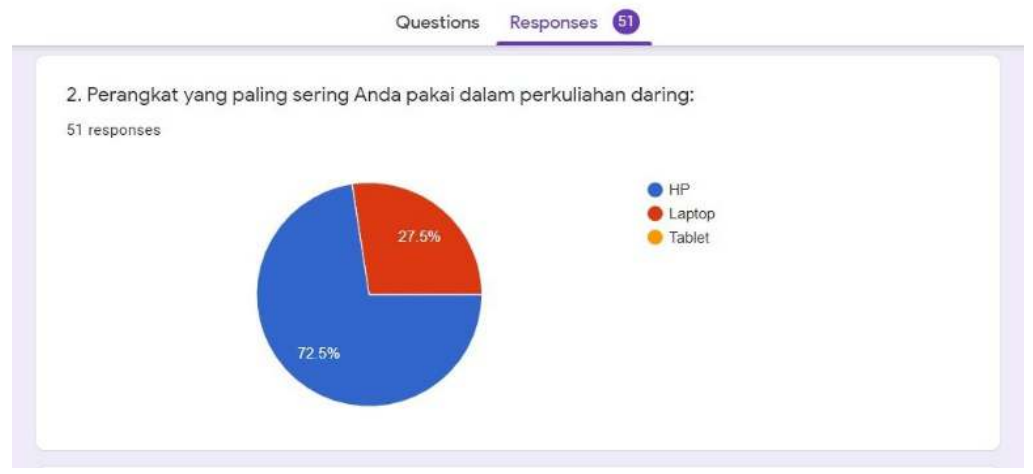

Fig. 3. Grafik jenis perangkat

Pertanyaan ke dua adalah tentang perangkat yang digunakan selama mengikuti pembelajaran daring. 72,5\% yaitu 39 mahasiswa dari 51 mahasiswa menggunakan handphone, sisanya yaitu 27,5\% menggunakan laptop. Hal ini cukup wajar karena handphone memang lebih mudah dalam mengakses materi pembelajaran maupun informasi kelas terbaru di mana saja dan kapan saja.

\section{Tingkat kesulitan menggunakan SPADA sebagai media pembelajaran}

Pembelajaran Bahasa Inggris di Teknik Mesin S1 lebih banyak menggunakan SPADA ITN Malang sebagai platform utama untuk membagi materi dan tugas, absensi, juga untuk mengumpulkan tugas. Pertanyaan ke 3 menanyakan tentang tingkat kesulitan dalam mengoperasikan SPADA ITN Malang selama pembelajaran, yang hasilnya disajikan pada Fig. 4.

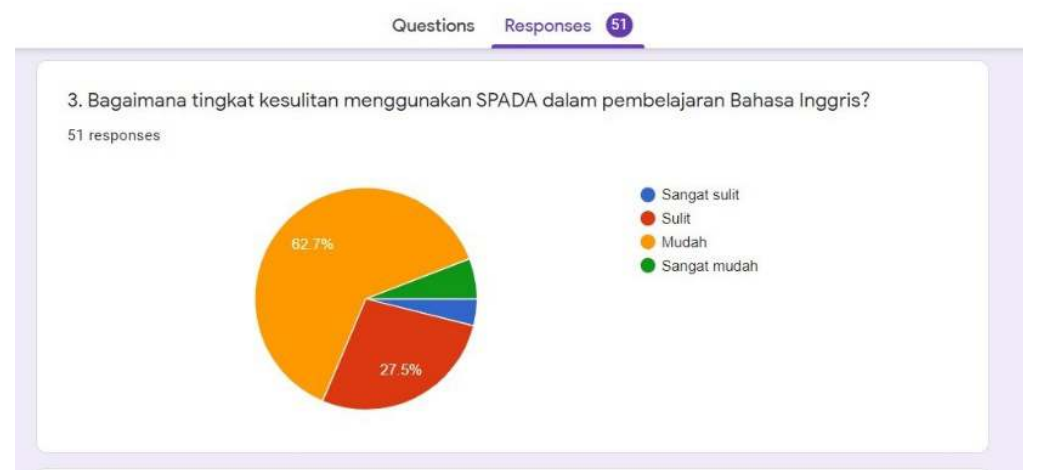

Fig. 4. Grafik tingkat kesulitan mengoperasikan SPADA 


\section{Tingkat kesulitan materi yang diberikan oleh dosen selama e-learning}

Fig. 5. menunjukkan bahwa materi yang diberikan tidak terlalu sulit, bahkan mudah dipahami. Dosen berkomitmen untuk memberikan materi yang lebih disederhanakan dan sesuai untuk pembelajaran daring, sehingga hanya $15,7 \%$ yaitu 8 mahasiswa dari 51 yang menyatakan materi sulit.

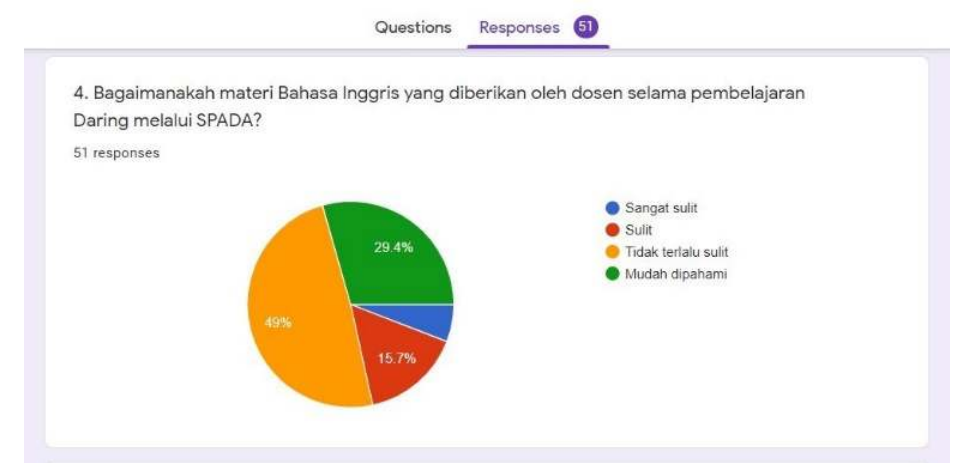

Fig. 5. Grafik tingkat kesulitan materi

\section{Tingkat pemahaman terhadap materi yang ada di SPADA}

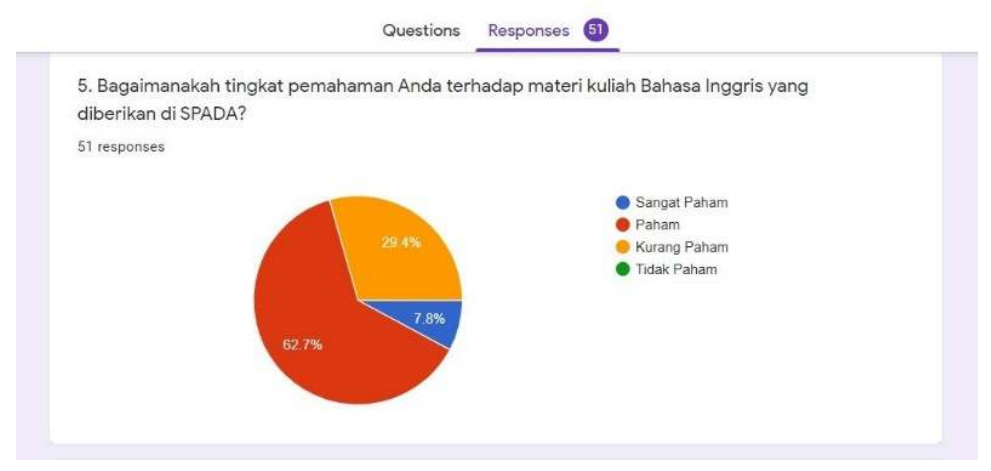

Fig. 6. Grafik tingkat pemahaman

Terkait dengan pertanyaan ke 4 tentang tingkat kesulitan materi yang diberikan oleh dosen, pertanyaan ke 5 melakukan konfirmasi terhadap tingkat pemahaman mahasiswa terhadap materi yang diberikan. Fig. 6 . menunjukkan bahwa tingkat pemahaman sesuai dengan mayoritas jawaban yang ditunjukkan pada Fig. 5. Grafik tingkat kesulitan materi. Hanya 29,4\% responden yaitu 14 dari 51 mahasiswa yang menyatakan kurang paham terhadap materi. Bahkan tidak ada jawaban "Tidak Paham" dalam respon.

\section{Deskripsi singkat kesulitan dalam proses mengumpulkan tugas di SPADA}

Penyediaan materi dan pengumpulan tugas dilakukan dengan memakai platform SPADA ITN Malang, yang memakan bandwith lebih sedikit dan mudah diakses dari telepon seluler. Pada perkuliahan daring Bahasa Inggris, pengumpulan tugas diberi waktu pengerjaan selama 1 hingga 2 minggu, agar mahasiswa memiliki waktu yang cukup untuk mengerjakan sekaligus mengumpulkan saat terkendala jaringan internet.

Enam (6) responden menjawab tidak ada kesulitan dalam mengumpulkan tugas, karena instruksi sudah jelas dan waktu yang diberikan sudah cukup. Responden yang lain mengungkapkan kesulitan terbesar adalah masalah koneksi internet, paket data dan jaringan terbatas. Selama pandemi ini, sebagian besar mahasiswa kembali ke kampung halaman mereka, sehingga dapat dipahami bahwa koneksi internet yang didapat bisa jadi tidak sebaik ketika berada di kota Malang. 8 responden menyampaikan bahwa kuota data menipis dan mahal. Hal ini sebenarnya telah diatasi dengan program pemberian paket data gratis oleh Kemdikbud dan ITN Malang pada seluruh mahasiswa. 


\section{Layanan dosen selama pembelajaran daring}

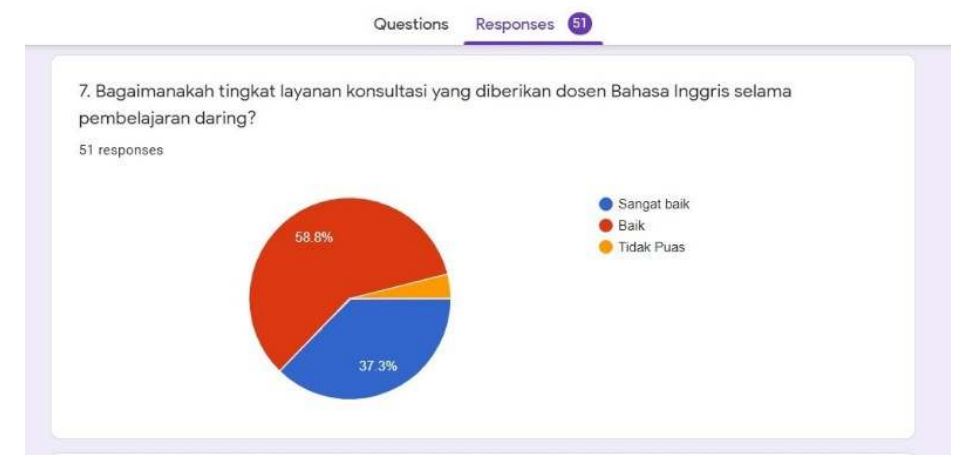

Fig. 7. Grafik layanan dosen selama pembelajaran daring

Selama pembelajaran daring, dosen memiliki peran yang paling penting dalam membimbing mahasiswa untuk memahami materi yang diberikan. Dosen diharapkan memberikan perhatian lebih dari pembelajaran luring, dimana mahasiswa telah bisa berdiskusi dengan dosennya maupun rekan sekelas ketika pembelajaran di kelas berlangsung. Dari hasil responden yang ditunjukkan pada Fig. 7, 97\% responden yaitu sebanyak 50 dari 51 mahasiswa menyatakan bahwa layanan konsultasi dosen selama daring ini sudah sangat baik. Dapat disimpulkan bahwa dosen bersedia untuk memberikan layanan pembimbingan lebih dari ketika pembelajaran luring.

\section{Kendala yang dialami selama pembelajaran daring}

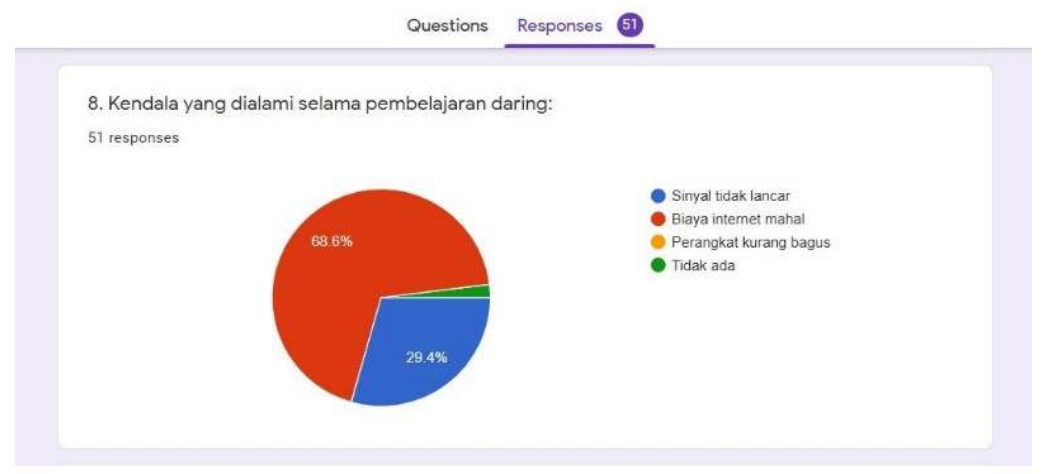

Fig. 8. Grafik kendala yang dialami

Bagi mahasiswa Teknik Mesin S1 ITN Malang, pembelajaran daring kali ini adalah yang pertama kali dialami, sehingga terdapat banyak penyesuaian. Karena perkuliahan diliburkan, mayoritas mahasiswa kembali ke kota/daerah asal. Hal ini menyebabkan bervariasinya tingkat koneksi internet yang didapat selama pembelajaran berlangsung. Ketika ditanya tentang kendala yang dialami selama pembelajaran daring, mayoritas responden yaitu 68,6\% (35 mahasiswa) menyatakan bahwa biaya internet mahal, meskipun ada bantuan paket data dari Kemdikbud dan dari ITN sendiri berupa uang tunai untuk membeli paket data. 29\% responden menyatakan koneksi internet di daerahnya tidak lancar, sehingga ketika dipakai untuk pembelajaran yang menggunakan Zoom maupun Meet, koneksinya terputus-putus. Selain dari 2 kendala tersebut, tidak ada masalah dengan perangkat karena seluruh platform yang digunakan dalam pembelajaran daring Bahasa Inggris ini semuanya bisa diakses melalui ponsel. 


\section{Jenis platform yang paling mudah untuk digunakan selama pembelajaran}

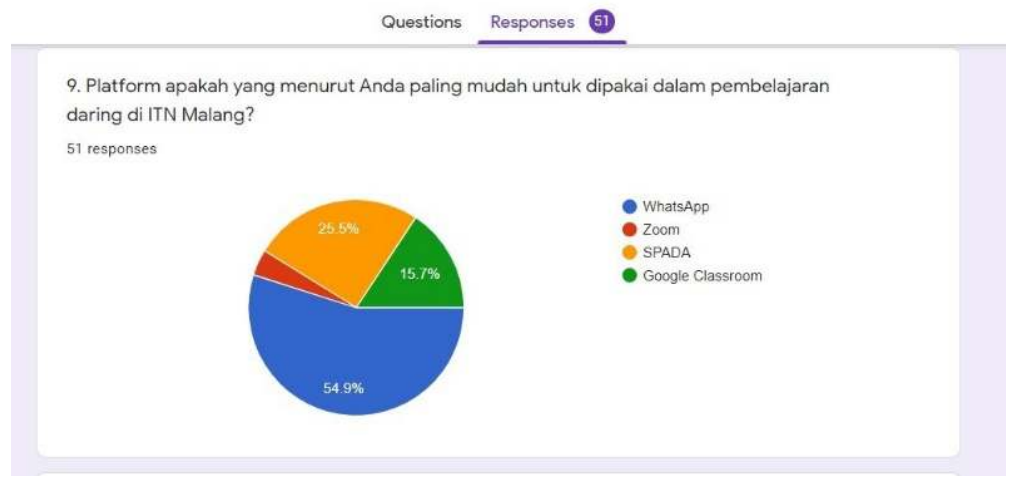

Fig. 9. Grafik jenis platform yang paling mudah

Terkait jenis platform yang paling mudah untuk digunakan dalam pembelajaran daring, sebanyak 55\% dari responden yaitu 28 mahasiswa memilih Whatsapp sebagai platform yang paling mudah dimengerti untuk digunakan. Hal ini dapat dimengerti karena dalam whatsapp, mahasiswa dapat langsung berdiskusi dengan dosen dan teman-teman sekelas di sebuah forum chat. Sementara 25,5\% yaitu 13 mahasiswa menjawab SPADA lebih mudah untuk digunakan.

\section{Deskripsi saran/tanggapan Anda untuk pelaksanaan pembelajaran daring}

Isian kuisioner ke 10 meminta agar mahasiswa memberikan tanggapannya terhadap pembelajaran daring yang telah dilakukan selama 1 semester. Harapan yang terbanyak adalah memberikan toleransi lebih maupun batas waktu pengumpulan tugas yang lebih lama sehingga bagi yang mengalami kendala sinyal tidak tertinggal, mengingat sinyal di daerah tidak stabil. Kedua, perlu biaya lebih untuk membeli paket data internet. Berikutnya, meningkatkan kualitas pemberian informasi (materi) bagi setiap mahasiswa agar lebih paham tentang pembelajaran daring, karena beberapa mahasiswa menyatakan kurang paham dengan materi yang diberikan secara daring.

\section{Deskripsi Hasil Wawancara}

Wawancara yang telah dilakukan terhadap dosen Bahasa Inggris dan 10 mahasiswa menunjukkan hasil yang tidak terlalu beragam. Terdapat banyak kesamaan jawaban dalam 5 poin pertanyaan yang diajukan. Berikut adalah daftar pertanyaan yang diajukan:

1. Apakah anda mengikuti perkuliahan daring secara aktif dan penuh?

2. Apakah dosen Pengampu Mata Kuliah menawarkan pilihan media pembelajaran yang akan digunakan di kelas online?

3. Apakah dosen Pengampu Mata Kuliah membantu anda ketika anda kesulitan dalam menggunakan media pembelajaran online?

4. Apakah dosen Pengampu Mata Kuliah memberikan instruksi yang jelas tentang prosedur pembelajaran kelas online (cara mengakses materi, prosedur pengumpulan tugas, memberikan feedback)?

5. Apakah anda menghadapi kendala saat menggunakan media pembelajaran daring? Kalau ada sebutkan.

6. Media pembelajaran apa saja yang anda gunakan ketika mengikuti kelas online ?

7. Menurut anda, dari media pembelajaran yang anda sebutkan diatas, media mana yang membantu anda memahami materi secara efektif?

8. Menurut pengalaman Anda, bagaimana tingkat pemahaman anda dalam menyerap materi kuliah daring ?

9. Menurut anda, apakah ada perbedaan yang signifikan dalam memahami materi yang disampaikan dosen dalam menyampaikan materi secara luring/di kelas dan daring/online? Berikan alasan.

10. Apakah anda mempunyai usulan untuk fitur yang bisa ditambahkan di sistem pembelajaran/LMS (Learning Management System) SPADA ?.

Kuisioner yang dikirim kepada mahasiswa Teknik Mesin S1 ITN Malang sebanyak 120 kali dan mendapatkan 51 respon. Secara umum, hasil kuisioner menunjukkan bahwa platform yang dipakai selama pembelajaran daring Bahasa Inggris yaitu Whatsapp, LMS SPADA ITN Malang, dan Zoom telah cukup memadai dan membantu dalam pembelajaran mereka dalam penugasan yang lebih terstruktur. Tersedianya beberapa pilihan platform pembelajaran juga membuat pembelajaran menjadi lebih mudah diakses di mana saja dan kapan saja. Bantuan layanan konsultasi yang diberikan oleh dosen pengampu juga disebutkan sangat membantu dalam berlangsungnya pembelajaran daring yang baik.

Namun demikian, karena pembelajaran daring ini merupakan pengalaman daring yang pertama bagi mereka, terdapat beberapa kekurangan dan kendala yang mereka alami. Kesulitan terbesar adalah masalah koneksi internet, paket data yang mahal, dan jaringan seluler yang terbatas. Selama pandemi ini, sebagian besar mahasiswa kembali ke kampung halaman mereka, sehingga koneksi internet yang didapat bisa jadi tidak sebaik ketika berada di kota Malang. Mahalnya 
paket data juga membuat mahasiswa harus mengeluarkan uang lebih untuk membelinya, meskipun terdapat bantuan, belum cukup untuk mencukupi semua kebutuhan dari semua mata kuliah semester ini. Kesulitan berikutnya adalah kurangnya pemahaman terhadap materi perkuliahan yang diberikan. Hal ini terjadi karena keterbatasan untuk berinteraksi secara langsung dengan dosen pengampu mata kuliah, karena tidak seluruh pertemuan dari 14 pertemuan tersebut memakai video meeting seperti Zoom maupun Meet. Sehingga bagi mereka, luring memiliki nilai lebih karena mereka bisa berdiskusi yang tak terbatas dengan dosen maupun rekan sekelas untuk menyelesaikan suatu kendala, sehingga akan lebih efektif dalam memahami sebuah materi.

\section{KESIMPULAN DAN SARAN}

Hasil kuesioner menunjukkan bahwa tiga platform yang dipakai selama pembelajaran daring Bahasa Inggris yaitu Whatsapp, LMS SPADA ITN Malang, dan Zoom telah cukup memadai, membantu sharing atau penyampaian materi dalam pembelajaran, dan memudahkan dalam pengumpulan penugasan yang lebih terstruktur. Materi yang diberikan oleh dosen sudah disederhanakan sehingga bisa dipahami oleh sebagian besar mahasiswa, dibarengi dengan layanan konsultasi yang baik dari dosen pengampu mata kuliah. Hasil wawancara menunjukkan bahwa penerapan pembelajaran daring di Teknik Mesin S1 ITN Malang sudah cukup baik dalam hal fasilitas yang disediakan oleh ITN Malang melalui SPADA yang sudah mampu mengakomodasi kebutuhan pembelajaran, dan dalam pemberian instruksi oleh dosen pengampu mata kuliah yang sudah sangat jelas. Kekurangan dari pembelajaran daring ini yang disebutkan dalam kuisioner maupun hasil wawancara adalah pemahaman terhadap materi masih kurang karena kurangnya interaksi langsung dengan dosen dalam proses belajar mengajar.

Adapun saran bagi dosen pengampu Mata Kuliah Bahasa Inggris di Teknik Mesin S1 Institut Teknologi Nasional Malang perlu untuk lebih memaksimalkan metode dan media pembelajaran yang digunakan dalam pembelajaran daring. Penggunaan video yang dibuat oleh dosen bisa lebih membantu mahasiswa dalam memahami materi yang diberikan, saat tidak sedang memakai platform berbasis video call seperti Zoom maupun Google Meet. Bagi peneliti selanjutnya untuk dapat meneliti metode pembelajaran yang lebih efektif dalam memaksimalkan pemahaman mahasiswa, disertai dengan instruksi maupun buku ajar atau modul yang bisa disesuaikan dengan capaian pembelajaran di kelas.

\section{REFERENCES}

[1] Anderson, T., Elloumi, F. (2004). Theory and Practice of Online Learning. Canada: Athabasca University.

[2] Dabbagh, N. \& Bannan-Ritland, B. (2005). Online learning: Concept, strategies, and application. New Jersey: Pearson education, Inc.

[3] Gunawan, Imam. Metode Penelitian Kualitatif. Malang: Universitas Negeri Malang

[4] H.B. Sutopo. 2006. Metodologi Penelitian Kualitatif : Dasar teori dan Terapannya dalam Penelitian. Surakarta: Universitas Sebelas Maret.

[5] Maudiarti, Santi. 2018. Penerapan E-Learning Di Perguruan Tinggi. PERSPEKTIF Ilmu Pendidikan - Vol. 32 No. 1 April 2018.

[6] Sutopo. 2006. Metodologi Penelitian Kualitatif. Surakarta: UNS.

[7] Wahono, R.S. (2008). Meluruskan salah kaprah tentang e-learning. http://romisatriawahono.net/2008/01/23/meluruskan-salahkaprah-tentang-elearning/ diakses 10 Oktober 2020 